\title{
Marine snow-oil interaction Affects $n$-Alkane biodegradation in sediment
}

\author{
Shokouh Rahsepar · Justine S. van Eenennaam · Jagoš R. Radović $\cdot$ \\ Thomas B. P. Oldenburg • Huub H. M. Rijnaarts • Albertinka J. Murk • \\ Edwin M. Foekema $\cdot$ Alette A. M. Langenhoff
}

Received: 6 May 2021 / Accepted: 16 February 2022 / Published online: 28 February 2022

(C) Springer Nature Switzerland AG 2022

\begin{abstract}
During the Deepwater Horizon (DwH) oil spill, an excessive production of marine snow was observed, and it was estimated that as much as $14 \%$ of the oil was transferred to the ocean floor by MOSSFA (Marine Oil Snow Sedimentation and Flocculent Accumulation). MOSSFA is an important pathway of transferring oil to the ocean floor. We performed experiments at laboratory scale in 15 aquaria, representing 5 exposures of marine snow with or without
\end{abstract}

Supplementary Information The online version contains supplementary material available at https://doi. org/10.1007/s11270-022-05557-1.

S. Rahsepar · J. S. van Eenennaam - H. H. M. Rijnaarts · A. A. M. Langenhoff $(\square)$

Sub-Department of Environmental Technology, Wageningen University \& Research, P.O. Box 17, 6700 AA Wageningen, The Netherlands e-mail: alette.langenhoff@wur.nl

J. R. Radović · T. B. P. Oldenburg PRG, Department of Geoscience, University of Calgary, 2500 University Drive NW, Calgary, AB T2N 1N4, Canada

\section{A. J. Murk · E. M. Foekema}

Marine Animal Ecology Group, Wageningen University \& Research, P.O. Box 338, 6700 AH Wageningen, The Netherlands

\section{E. M. Foekema}

Wageningen Marine Research, Wageningen University \& Research, P.O. Box 57, 1780 AB Den Helder,

The Netherlands oil, only oil, and controls with only clay or sediment. We developed a method to produce artificial marine snow, which resembles the natural marine snow. Results showed $40 \%$ less biodegradation of alkanes in "marine snow with oil" compared to "only oil." Most probably, this is due to preferred biodegradation of marine snow organics comparing to oil alkanes. Biodegradation of marine snow reduces the dissolved oxygen concentration, which might result in anaerobic conditions in the sediment layer. This finding can be projected to a potential ocean floor effect.

Keywords Biodegradation - Marine snow - Oil spill $\cdot$ Sediment $\cdot$ MOSSFA $\cdot$ Deepwater Horizon

\section{Introduction}

The Deepwater Horizon (DwH) oil drilling rig in the Gulf of Mexico (GoM) exploded on April 2010, causing the release of roughly $500,000 \mathrm{~m}^{3}$ of Macondo well oil over the course of 87 days (Beyer et al., 2016). To prevent oil surfacing and to maintain the spilled oil in the water column, a response operation was applied. About $8000 \mathrm{~m}^{3}$ chemical dispersants (Corexit EC9500A and EC9527A) were applied, of which $60 \%$ to the water surface, and $40 \%$ to the DwH wellhead at a depth of $1500 \mathrm{~m}$ close to the ocean floor (Beyer et al., 2016; Kujawinski et al., 2011). The released oil from the wellhead formed droplets in different sizes due to pressure differences between 
the oil reservoir and the water column, and droplet formation was further enhanced by the chemical dispersant injection (Malone et al., 2018; Peterson et al., 2012). Dispersants reduce the oil-water interfacial tension (Soloviev et al., 2016), thereby breaking oil into smaller and more stable suspended droplets than occurs by natural dispersion (Zeinstra-Helfrich et al., 2015). The resulting larger oil-water surface area increases oil dissolution and the bioavailability for oil-degrading microbes (Doyle et al., 2018). Oil droplets migrate through the water column depending on droplet sizes and buoyancy. A portion of the spilled oil with smaller droplet sizes and lower density remains suspended while forming oil plumes, either in the water column or (partly) at the water surface. Although chemical dispersants injected at the wellhead aim to prevent oil from reaching the water surface and thereby threatening shorelines, some portion of the oil surfaced anyway (MacDonald et al., 2015). Dispersants applied at the surface enhance further droplet dispersion, dissolution of lighter oil components, and subsequently trigger settling of heavier components into the water column (Kleindienst et al., 2015; MacDonald et al., 2015; Zuijdgeest \& Huettel, 2012).

The excessive formation of marine snow reported during the DwH oil spill was a consequence of the formation of extracellular polymeric substances (EPS) (Passow et al., 2012) These are produced either as natural oil dispersants by free-living oil-degrading bacteria, or as a stress response by bacteria living in symbiosis with phytoplankton (Wotton, 2004) that are triggered by the presence of chemical dispersants and oil compounds. Phytoplankton is generally considered the main contributor to natural marine snow formation (Daly et al., 2016; Hastings et al., 2016; Passow et al., 2012; Sohm et al., 2011; van Eenennaam et al., 2016, 2019). Marine snow occurs naturally in the ocean, and gravitational setting of this material is responsible for carbon cycle and nutrient transport from upper layers to the deeper layers of the ocean (Wimpenny \& Poole, 2009). During oil spills, oil droplets interact and aggregate with marine snow and get transported to the ocean floor. This mechanism was the main pathway of transferring the oil to the sediment layer in the case of the DwH oil spill (Hastings et al., 2016; Romero et al., 2015). The process of settling of marine snow-associated oil is called Marine Oil Snow Sedimentation and Flocculent Accumulation (MOSSFA).

Interaction of oil droplets with marine snow increases the oil surface area (Gregson et al., 2021; Lee et al., 2002), transfer between oil compounds and oil degrading microbes, and oil bioavailability. In the presence of marine snow oil degrading bacteria tend to attach to the marine snow, and this increases oil biodegradation (Rahsepar et al., 2017). Furthermore, mineral particles such as suspended clays can interact with marine snow and increase the marine snow gravitational settling speed. Elevated concentrations of suspended solids from the Mississippi river discharge and mud drilling close to the oil wellhead increased the oil droplets aggregations and eventually the settling to the sediment layer (Brooks et al., 2015; Yan et al., 2016). By transferring the oil droplets from the water column to the floor, the bioavailability of oil may decrease due to changes in the environmental conditions such as changed redox conditions or mass transfer limitations (Bagby et al., 2017).

Marine snow accumulated on the ocean floor up to $120-180 \mathrm{~km}$ from the wellhead (Stout et al., 2017), and deposition of marine snow-associated oil was observed as 1-6-cm thick oily deposits along the northeast GoM slope (Brooks et al., 2015). It is estimated that, after the DwH oil spill, up to $14 \%$ of the total spilled oil was transferred to the ocean floor by the sedimentation of marine snow-associated oil (Daly et al., 2016; Dissanayake et al., 2018). Mass accumulation rates increased from pre-spill to after spill during 2011 and 2012 by respectively $0.05-0.16 \mathrm{~g} / \mathrm{cm}^{2} /$ year to $0.48-2.40 \mathrm{~g} / \mathrm{cm}^{2} /$ year (Daly et al., 2016). The oxygen concentrations at a depth of 1000-1200 m such as in the GoM are generally in the range of $2.57 \pm 0.5 \mathrm{mg} / \mathrm{L}$ (Campbell et al., 2019). Aerobic processes can thus take place in the sediment layer, which will deplete the dissolved oxygen. Continued oxygen consumption in the sediment depends on diffusion of oxygen from the water column into the sediment (Camilli et al., 2010; Schwing et al., 2020). There are various papers that describe a MOSSFA event and the transfer of oil to the sediment layers at the ocean floor (Chanton et al., 2015; Quigg et al., 2020; Romero et al., 2017; Schwing et al., 2018; Stout et al., 2016); however, the fate and biodegradation of hydrocarbons in the deposited marine snow-associated oil are not well studied. 
We hypothesize that increases in organic matter content at the ocean floor will increase the oxygen consumption, which limits the availability of dissolved oxygen for degradation of oil compounds. The aim of this study is to elucidate the degradation of oil and specifically degradation of $n$-alkanes when oil is associated with marine snow. The degradation of $n$-alkanes was studied in 15 mesocosm aquaria with natural marine sediment in combination with artificial marine snow with or without oil, only oil, and controls with only clay or only sediment. The degradation of $n$-alkanes in these aquaria was studied during an incubation period of 42 days.

\section{Materials and Methods}

\subsection{Experimental Setup}

Oil biodegradation experiments were performed in 15 mesocosm aquaria of $25 \times 25 \times 25 \mathrm{~cm}$, representing five different exposure conditions in triplicate (Table 1). Climate was controlled at $14{ }^{\circ} \mathrm{C}$, with a day-night light regime of 16-h light and 8-h dark.

The setup of the experiments and exposure preparation and sampling was similar to van Eenennaam et al. (2018). In short, the aquaria contained a $5 \mathrm{~cm}$ layer $(\approx 3.2 \mathrm{~L})$ of sieved $(1 \mathrm{~mm})$ natural uncontaminated sediment and a 15 -cm layer $(\approx 9.4 \mathrm{~L})$ of filtered $(0.45 \mu \mathrm{m})$ natural seawater. At the exposure day, depending on the exposure conditions, a 1-cm layer of marine snow with or without oil, or $3.15 \mathrm{~g}$ of clay with or without oil, was applied on top of the sediment layer, as described in details in Sect. 2.2. Clay is a component of the artificial snow and was present in all experimental conditions except the "sediment only" control.

Table 1 Overview of the exposure conditions for the aquarium experiment

\begin{tabular}{llll}
\hline Exposures & Marine snow & Oil & Kaolin clay \\
\hline Sediment control & - & - & - \\
Clay control & - & - & + \\
Snow & + & - & + \\
Oil & - & + & + \\
Snow +oil & + & + & + \\
\hline
\end{tabular}

"+" indicates present in the aquarium, and "- " indicates absent from the aquarium
The aquaria were covered with acrylic plastic covers to minimize water evaporation, and air was bubbled in the top $5 \mathrm{~cm}$ of the water column through two glass Pasteur pipettes per aquarium via an air pump. This aeration resulted in a continuous supply of oxygen, that did not get depleted in our experiments.

Sediment core samples for chemical analysis were taken from each aquarium at days 1, 16, 30, and 42 . The volume of sediment recovered in each core was approximately $9 \mathrm{~cm}^{3}$. At each sampling time, 4 samples were taken from different locations in one aquarium which were pooled to get a representative sample per aquarium. The samples were freeze-dried using a Christ Alpha 2-4 LDplus freeze dryer (Martin Christ Gefriertrocknungsanlagen $\mathrm{GmbH}$, Osterode am Harz, Germany), followed by extraction for chemical analysis (see Sect. 2.3).

We used surrogate Macondo oil in our experiment, kindly provided by BP, a light oil chemically similar to the Macondo oil of the DwH oil spill (BP Gulf Science Data, 2017). The oil added to our experiments showed the typical unimodal distribution peaking at $\mathrm{n}-\mathrm{C} 17$, that is characteristic of light oils, such as Macondo well oil.

The sediment did contain background levels of $n$-alkanes and isoprenoid alkanes; however, they showed distribution characteristic of natural biogenic input (i.e., odd over even preference), such as algae (Gelpi et al., 1970; Li et al., 2016).

Uncontaminated natural seawater was collected from the Eastern Scheldt, The Netherlands, filtered over a $0.45-\mu \mathrm{m}$ filter and stored in a tank in the laboratory.

In order to kick-start the biodegradation of oil, two oil-degrading microorganisms were added to the water column at day 1. Rhodococcus qingshengii TUHH-12 (DSMZ No. 46766) was used as an alkanedegrading culture, and Pseudomonas putida F1 (DSMZ, No. 6899), an aromatic degrading culture, were prepared and handled according to Rahsepar et al. (2016) and Schedler et al. (2014). Cultures of $R$. TUHH-12 and $P$. F1 were grown in seawater-mineral media supplied with $n$-hexadecane or toluene, respectively, as described by Rahsepar et al. (2016). One milliliter of mid-exponential phase of each culture $(\mathrm{OD} 600=0.98, R$. TUHH-12 and OD600 $=0.30$, $P$. F1) was added to the water column of each aquarium on day 1. All the exposures contained these two cultures. 


\subsection{Artificial Marine Snow Production}

EPS, including proteins and polysaccharides, was produced in our laboratory by exposing phytoplankton communities to chemical dispersants (van Eenennaam et al., 2016). However, in this way, it was not feasible to produce sufficient amounts of EPS for the amount of marine snow needed for this study. Therefore, a method was developed to produce artificial marine snow which resembles the natural marine snow. Based on the natural marine snow composition reported for the MOSSFA event during the DwH oil spill, the following essential ingredients for production of the artificial marine snow were defined: alginate-like exopolysaccharides, phytoplankton biomass, and mineral particles (Alldredge \& Silver, 1988; Daly et al., 2016; Thornton, 2002; van Eenennaam et al., 2016). This artificial marine snow was used to study the effect of association of oil with marine snow on $n$-alkanes (C13-C30) biodegradation in this study.

Artificial marine snow was prepared by adding $22.5 \mathrm{~g}$ of commercially available alginate (alginic acid sodium salt, CAS 9005-38-3 Sigma-Aldrich), a gelling and nontoxic anionic polysaccharide, to 1.1 $\mathrm{L}$ of filtered natural seawater while stirring. Then, $9.45 \mathrm{~g}$ of kaolin clay (hydrated aluminum silicate, CAS 1332-58-7, Sigma-Aldrich) and $19 \mathrm{~g}$ of fresh weight of phytoplankton biomass (Chlorella paste, Ingrepro BV, Borculo, The Netherlands) were added to the solution. Separately, $188 \mathrm{~g}$ of $\mathrm{CaCl}_{2}$ (CAS 10043-52-4, Fluka Analytical) was dissolved in 13 $\mathrm{L}$ of demi-water, and this solution was added to the alginate solution while stirring. The calcium causes coagulation of the alginate and precipitation of 600$\mathrm{mL}$ marine-snow-like particles. The overlying liquid was poured off, and the artificial marine snow was divided into three equal parts for the three aquaria replicates.

To prepare each replicate of snow-only exposure, $200 \mathrm{~mL}$ of this artificial marine snow was added to the aquaria resulting in an approximately 1 -cm-thick layer on top of the sediment. For the snow + oil exposure, the procedure was similar as described above except that the kaolin clay was first mixed with $1.9 \mathrm{~g}$ of oil and $100 \mathrm{~mL}$ demi-water before adding it to the alginate solution. For each replicate of the clay control, the kaolin clay was mixed with approximately $500 \mathrm{~mL}$ of seawater from the aquarium to form a suspension and then added to the aquaria. The clay settled on top of the sediment in a homogenous layer of approximately $0.5 \mathrm{~mm}$ thick. The oil-only exposure was prepared per aquarium by mixing $3.15 \mathrm{~g}$ of kaolin clay with $0.63 \mathrm{~g}$ of oil and $100 \mathrm{~mL}$ of demiwater to form a homogenous slurry that was added to the aquarium. To the sediment control aquaria, nothing extra was added.

\subsection{Monitored Water Parameters}

Dissolved oxygen (mg/L), $\mathrm{pH}(-)$, temperature $\left({ }^{\circ} \mathrm{C}\right)$, and salinity $(\% \circ)$ were monitored weekly during the experiment in the water phase at $10 \mathrm{~cm}$ above the sediment. The $\mathrm{pH}$ was measured with a Mettler Toledo $\mathrm{pH}$ probe, and the dissolved oxygen, temperature, and salinity with a Hach HQ40d multimeter using dissolved oxygen, salinity, and temperature probes.

The oxygen was intended to be measured at various depths in aquaria, especially below the sediment layer, at the interface of sediment and water, and just above the sediment layer. Oxi-dots were adjusted inside the aquarium glass before adding sediment and water. However, we could not measure dissolved oxygen via oxi-dots during the experiments due to technical problems. Therefore, the dissolved oxygen was analyzed only in the water column via Hach HQ40d multimeter.

\subsection{Chemical Analyses}

The sample preparation and analysis method were similar to Larter et al. (2019). In short, $5 \mathrm{~g}$ of freezedried sediment was extracted with $8 \mathrm{~mL}$ dichloromethane. An aliquot of the whole extract was first analyzed using GC-MS to check if the oil fingerprint was present. The temperature program for the GC-MS analysis included a hold of $5 \mathrm{~min}$ at $40{ }^{\circ} \mathrm{C}$, followed by a $4{ }^{\circ} \mathrm{C} / \mathrm{min}$ ramp up to $325^{\circ} \mathrm{C}$, and finishing with an isothermal hold at $325^{\circ} \mathrm{C}$ for $15 \mathrm{~min}$. Separation was performed on a HP-5MS capillary column $(30 \mathrm{~m} \times 0.25 \mathrm{~mm} \times 0.25 \mu \mathrm{m})$, and helium was used as carrier gas, at a flow of $1.0 \mathrm{~mL} / \mathrm{min}$. The mass spectrometer was acquiring data in a combined full scan/selected ion monitoring (SIM-SCAN) mode. SIM trace at $\mathrm{m} / \mathrm{z} 85$ was used to integrate the areas of $n$-alkanes (C13-C30) and isoprenoid alkanes (pristane and phytane). Integrated areas were then normalized to the area of C30-hopane $(17 \alpha(\mathrm{H}), 21 \beta(\mathrm{H})$-hopane) at SIM trace $\mathrm{m} / \mathrm{z}$ 191. C30-hopane is considered a 
conservative biomarker due to its recalcitrance to weathering (Prince et al., 1994). This normalization approach is typically used in oil spill studies to detect and compare compositional changes due to evaporation, biodegradation, and other weathering processes (Aeppli et al., 2014; Radović et al., 2014).

To demonstrate the stability and persistence of C30-hopane during our experiments and to confirm the validity of C30-hopane normalization, additional batch experiments were performed. The concentration of C30-hopane was followed during 42 days in 4 batches (1L), similar to the aquaria exposure snow + oil. The whole content of two bottles was extracted at day 0 and the other 2 extracted at day 42. The samples were analyzed using GC-MS as described above, and the C30-hopane was quantified against an internal standard of cholestane- $d_{4}$, assuming a relative response factor of 1 (Bennett \& Larter, 2000).

\subsection{Statistical Analysis}

GraphPad Prism 5 was used to perform statistical analysis using two-way ANOVA with Bonferroni multiple comparisons post-test. Results of statistical analyses are provided as Supplementary Material S1.

\section{Results}

\subsection{Physical Parameters in the Water Phase}

In the absence of marine snow, the oxygen concentration in the water column $10 \mathrm{~cm}$ above the sediment layer was stable during the incubation time of 42 days $(8 \mathrm{mg} / \mathrm{L} \pm 0.3 \mathrm{mg} / \mathrm{L})$. In the marine snowonly exposure, the oxygen concentration in the water phase dropped to $5.3 \pm 0.3 \mathrm{mg} / \mathrm{L}$ at day 6 , followed by a rebound to the initial value at day 10 (Fig. 1). The highest oxygen consumption was observed in the snow + oil exposure. The oxygen concentration in the water dropped significantly from $9 \pm 0.5 \mathrm{mg} / \mathrm{L}$ to values varying around $4.4 \pm 0.5 \mathrm{mg} / \mathrm{L}$ in the first 6 days, whereafter it returned to the initial oxygen concentration within 4 days (Fig. 1).

The $\mathrm{pH}$, temperature, and salinity in the water phase remained constant during the incubation time in all the exposures at an average value of $8.5 \pm 0.3$,

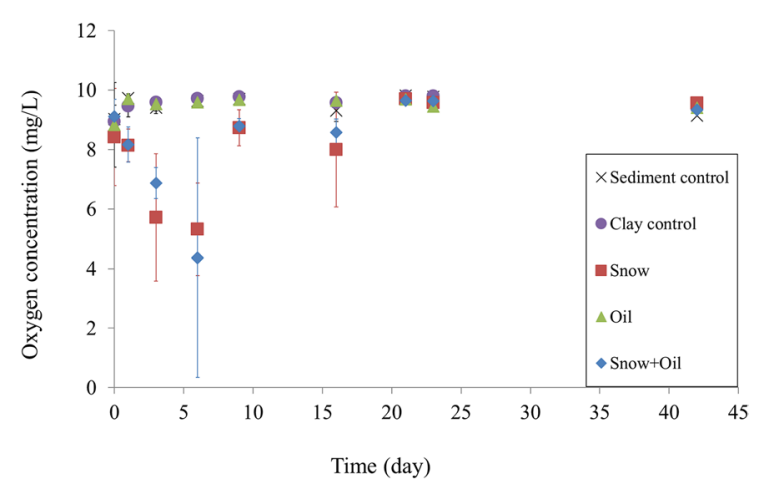

Fig. 1 Dissolved oxygen concentration at $10 \mathrm{~cm}$ above the sediment layer in the water phase of the aquarium. Average and standard deviation of three aquaria replicates

$14{ }^{\circ} \mathrm{C} \pm 1{ }^{\circ} \mathrm{C}$, and $34 \% \pm 2 \%$, respectively (Supplementary Material S2).

\subsection{C30-Hopane Normalized n-Alkanes (C13-C30) and Isoprenoid Alkanes}

The batch experiments confirmed the persistence of C30-hopane during our experiments, with average duplicate concentrations of 180 and $210 \mu \mathrm{g}$ of C30hopane per $\mathrm{g}$ of sediment extracted at $t=0$ and $t=42$, respectively. The observed variability (approx. 10\% relative standard deviation) is within the acceptable limit of analytical error accumulated during experimental setup, sampling, sample preparation, GC-MS analysis, and peak integration. Therefore, hopane normalized peak areas were further used to determine the relative abundance changes of $n$-alkanes and isoprenoid alkanes.

The C30-hopane normalized peak areas of the $n$-alkanes (C13-C30) and isoprenoid alkanes determined in samples of the exposures oil and snow + oil are presented in Fig. 2 (see Supplementary Material S3 for oil chromatograms related to conditions "only oil" and "snow+oil"). The results show that 2.5 times more $n$-alkanes and isoprenoid alkanes were degraded in the absence of marine snow $(65 \%)$ than in the presence of marine snow (25\%).

Figure 3 shows depletion of $n$-alkanes and isoprenoids alkanes normalized with C30-hopane at the start and after day 42 of incubation. After 42 days of incubation, the relative removal (in \%) of all individual $n$-alkanes and isoprenoid alkanes was higher in the absence of marine snow (Fig. 4). In addition, 


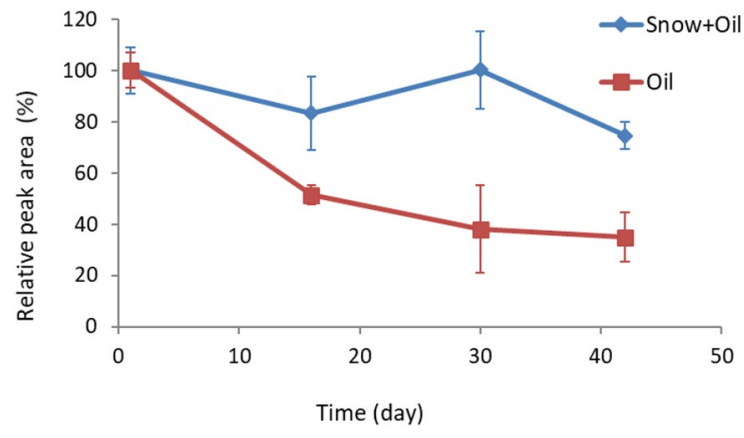

Fig. 2 Relative peak area of C30-hopane normalized $n$-alkanes (C13-C30) and isoprenoid alkanes (pristane and phytane). Average and standard deviation of three aquaria replicates

when looking at the individual removal percentages of the different $n$-alkanes and isoprenoid alkanes, the depletion of the smaller compounds $(<\mathrm{C} 18)$ is far more pronounced in the absence of marine snow.

\section{Discussion}

In this research, we studied $n$-alkane biodegradation, and the effect of oil association with organic and clay particles, during and after settling at a sediment layer in mesocosm aquaria. We observed $40 \%$ less $n$-alkane depletion when oil was in association with artificial marine snow compared to oil that was only associated with clay. This suggests that the organic component of the artificial marine snow influenced hydrocarbon depletion. Our results are in line with findings from a field study with sediment samples collected in the Gulf of Mexico after the DwH oil spill. This report describes the depletion of oxygen in the sediment layers after the DwH event (Hastings et al., 2016), which results in less biodegradation for many alkanes after deposition to the seafloor (Bagby et al., 2017).

In the presence of marine snow, the oxygen concentration in the water $10 \mathrm{~cm}$ above the sediment dropped from $9 \pm 0.5 \mathrm{mg} / \mathrm{L}$ to values of
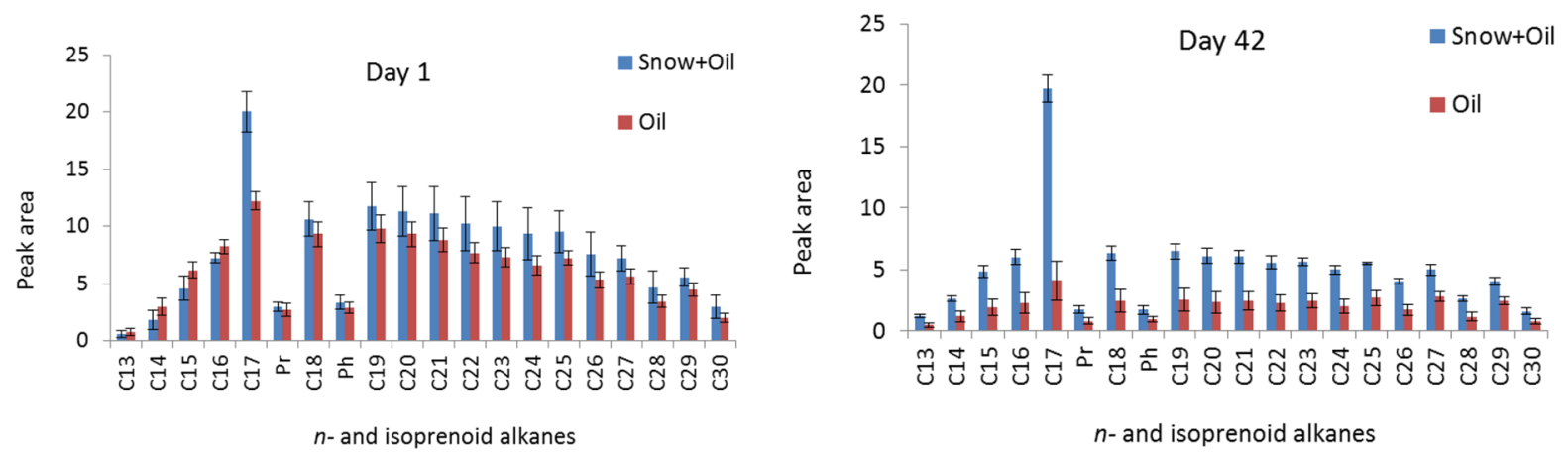

Fig. 3 C30-hopane normalized peak areas of $n$-alkanes (C13-C30) and isoprenoid alkanes (pristane and phytane) in sediment samples on day 1 (left) and day 42 (right). Average and standard deviation of three aquaria replicates

Fig. 4 Profile of removal percentage of $n$-alkanes (C13-C30) and isoprenoid alkanes (pristane and phytane) in sediment samples at day 42 compared to day 0 . Average and standard deviation of three aquaria replicates

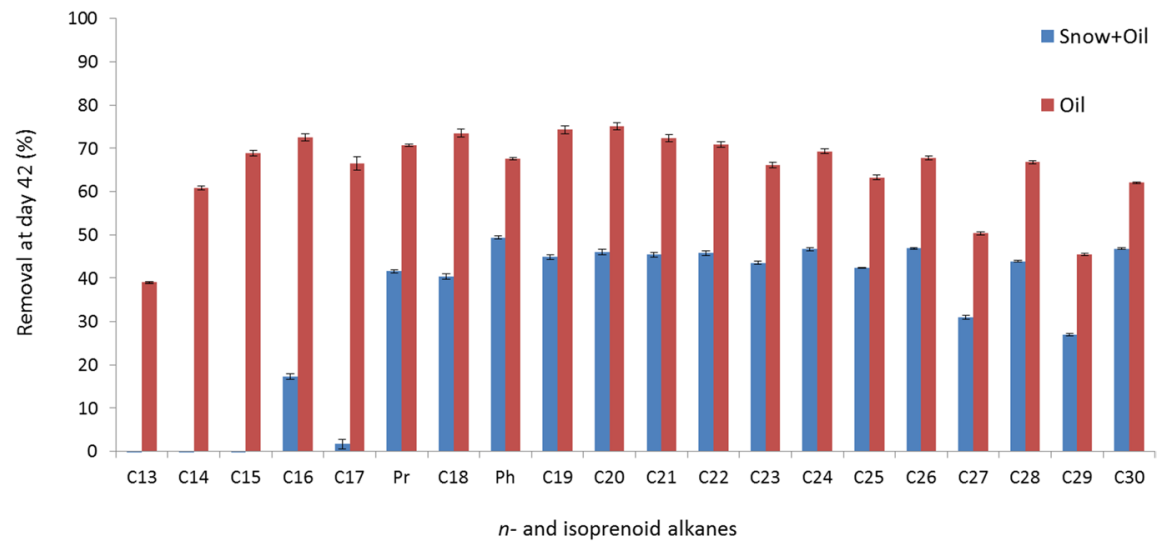


$4.4 \pm 0.5 \mathrm{mg} / \mathrm{L}$ after 6 days of incubation (Fig. 1), despite continuous gentle aeration at the water surface, suggesting enhanced oxygen consumption due to marine snow degradation.

Hydrocarbon degrading bacteria are not necessarily limited to the consumption of hydrocarbons as a carbon source. In general, these bacteria utilize hydrocarbons and other oil compounds as carbon and energy sources, when easily degradable carbon is not available. Physiological activity of bacteria and their metabolic enzymes determine the function and carbon source consumption by bacteria (Mukherjee et al., 2017; Xu et al., 2018).

However, mid-chain-length $n$-alkanes are suitable carbon and energy sources for some microbes, but most likely not for all microbes available in our system. When comparing the two conditions, "only oil" and "snow + oil," we saw $40 \%$ less depletion of hydrocarbons in the "snow + oil condition." Therefore, we assume that artificial marine snow was consumed as a carbon and energy source in our aquaria system rather than the $n$-alkanes. Both our artificial marine snow as well as natural marine snow contain carbon compounds that are easily degradable with concomitant oxygen use. Especially the carbohydrates of marine snow have oxidized groups in their molecular structures, which are readily available for further enzymatic conversions and mineralization (Alldredge \& Silver, 1988; Bochdansky et al., 2010; Gutierrez et al., 2018; Shanks \& Trent, 1980).

Relative to marine snow, oil is more recalcitrant to biodegradation because of its stable reduced aliphatic or aromatic molecular structures that need to be activated for further mineralization, i.e., through oxygen inclusion by oxygenases (Chikere et al., 2011; Nzila, 2018; Shrivastava \& Phale, 2012). As a result, biodegradation of oil components with half-lives up to 60 days, depending on the oxygen availability will be slower compared to, e.g., marine snow (Bagby et al., 2017; Prince et al., 2017; Reddy et al., 2012). Therefore, when both marine snow and oil are present, marine snow will be a preferred substrate over oil for the aerobic microbial community. Oil degradation is then further hampered by oxygen depletion as our results suggest.

In our experiment, reduced oxygen concentrations were detected in aquaria with marine snow (snow and snow + oil conditions) even though the dissolved oxygen measurement point was relatively far from the sediment surface ( $5 \mathrm{~cm}$ below the water surface). However, these reduced oxygen concentrations were not observed in the "only oil" condition, despite the higher alkane depletion at day 16. This is an indication that marine snow does have an $\mathrm{O}_{2}$ demand early in the experiment. Follow-up aquarium experiments including eco-toxicological effects on invertebrate organisms also demonstrated oxygen depletion in the sediment layer in the presence of marine snow (van Eenennaam et al., 2018). At the deep ocean floor, oxygen availability in the water phase nearby the sediment layer could be limited, depending on the depth and hydrological conditions. In addition, the water temperature in the Gulf of Mexico at 1500 -m depth is $\sim 4-6{ }^{\circ} \mathrm{C}$, which is lower than our experimental setup $\left(14^{\circ} \mathrm{C}\right)$, as the solubility of oxygen is higher at these cold temperatures; our experiments represent a "worst-case scenario" of the processes at the ocean floor in the Gulf of Mexico.

Depleted oxygen in the deep sea top sediment layer with more than $1 \mathrm{~cm}$ of marine snow-associated oil most likely contributed to the persistence of oil-sediment layers as reported for the DwH oil spill (Bagby et al., 2017) and the Ixtoc-I spill in 1979 (Lincoln et al., 2020), where MOSSFA had occurred as well (Lincoln et al., 2020; Vonk et al., 2015). Also, anaerobic conditions were detected in sediment layer after the DwH oil spill (Bacosa et al., 2018), suggesting that the presence of marine snow contributes to the expansion of anaerobic conditions, eventually limiting the oil biodegradation in these sediments. A study showed that the intensity of anaerobic conditions in the sediment layer of GoM lasted for up to 3 years after the DwH spill, likely as a result of excess organic matter and hydrocarbon burial and decomposition in the sediments (Daly et al., 2016; Foekema et al., 2020; Hastings et al., 2016).

Our results are consistent with our hypothesis that the $n$-alkanes biodegradation rate in the sediment layer is influenced by two related factors: carbon source competition and oxygen availability. When high concentrations of marine snow or other easily degradable carbon sources are present, aerobic biodegradation of marine snow is preferred, followed by the biodegradation of $n$-alkanes. The association of oil with marine snow by itself does not mean that the $n$-alkane biodegradation will decrease. In conditions without oxygen limitation, the inclusion of oil in marine snow could even increase the $n$-alkanes 
biodegradation as has been shown for the water phase (Rahsepar et al., 2017). In our experimental setup, we have not tested whether adding bacterial cultures to kick-start the biodegradation is necessary. However, the concept behind the "kick start" was related to the results of Rahsepar et al. (2016), which elucidated that the presence of aromatic compounds could interfere with the degradation of $n$-alkanes.

This experimental setup was initiated to develop a surrogate study system, because the real-world system is difficult to reach and to study. The laboratory setup of this experiment allowed us to specifically study the biodegradation of marine snow-associated oil on the sediment layer. We have expanded the experimental setup in other research (van Eenennaam et al., 2018) and included oxygen sensors to precisely monitor the dissolved oxygen levels. In this research, we observed enhanced $n$-alkane biodegradation in the presence of benthic invertebrates due to bioturbation and enhanced oxygen penetration into the sediment (van Eenennaam et al., 2018). This might further affect the biodegradation rate of oil which was investigated in an aquarium experiment with representative benthic invertebrates.

This fundamental knowledge is highly relevant to understand more complex systems. The limited availability of oxygen in the sediment layer can be enhanced by bioturbation activities of benthic organisms (Foekema et al., 2020; Pelegrí \& Blackburn, 1994).

\section{Conclusion}

This study shows that biodegradation of $n$-alkanes in top sediments was slowed down up to $40 \%$ when oil was associated with marine snow. We believe two correlated factors play a role in this slow biodegradation: carbon source competition and oxygen availability. Marine snow can enhance oil biodegradation in the abundance of oxygen. However, when the dissolved oxygen is a limiting factor, preferential oxygen consumption for the degradation of marine snow competes with oil degradation, thus slowing down the $n$-alkane biodegradation. This needs to be taken into account, when dealing with future oil spills.

Acknowledgements Jagoš R. Radović and Thomas B.P. Oldenburg acknowledge the support from the Canada Foundation for Innovation (CFI), the Natural Sciences and Engineering Research Council of Canada (NSERC) and Canada Research Chairs (CRC), PRG, and the University of Calgary. Practical help by Yulia Kuvshinova is gratefully acknowledged.

Funding This research was made possible by a grant from The Gulf of Mexico Research Initiative (Grant Contract \#SA 12-10/GoMRI-007) and by the Wageningen UR TripleP@ Sea innovation Program (KB-14-007).

Data Availability Data are publicly available through the Gulf of Mexico Research Initiative Information \& Data Cooperative (GRIIDC) at https://data.gulfresearchinitiative.org (doi:10.7266/N7125QPZ).

\section{Declarations}

Conflict of Interest The authors declare no competing interests.

Open Access This article is licensed under a Creative Commons Attribution 4.0 International License, which permits use, sharing, adaptation, distribution and reproduction in any medium or format, as long as you give appropriate credit to the original author(s) and the source, provide a link to the Creative Commons licence, and indicate if changes were made. The images or other third party material in this article are included in the article's Creative Commons licence, unless indicated otherwise in a credit line to the material. If material is not included in the article's Creative Commons licence and your intended use is not permitted by statutory regulation or exceeds the permitted use, you will need to obtain permission directly from the copyright holder. To view a copy of this licence, visit http://creativecommons.org/licenses/by/4.0/.

\section{References}

Aeppli, C., Nelson, R. K., Radović, J. R., Carmichael, C. A., Valentine, D. L., \& Reddy, C. M. (2014). Recalcitrance and degradation of petroleum biomarkers upon abiotic and biotic natural weathering of Deepwater Horizon oil. Environmental Science \& Technology, 48, 6726-6734. https://doi.org/10.1021/es500825q

Alldredge, A. L., \& Silver, M. W. (1988). Characteristics, dynamics and significance of marine snow. Progress in Oceanography, 20, 41-82. https://doi.org/10.1016/00796611(88)90053-5

Bacosa, H. P., Erdner, D. L., Rosenheim, B. E., Shetty, P., Seitz, K. W., Baker, B. J., \& Liu, Z. (2018). Hydrocarbon degradation and response of seafloor sediment bacterial community in the northern Gulf of Mexico to light 
Louisiana sweet crude oil. The ISME Journal, 12, 25322543. https://doi.org/10.1038/s41396-018-0190-1

Bagby, S. C., Reddy, C. M., Aeppli, C., Fisher, G. B., \& Valentine, D. L. (2017). Persistence and biodegradation of oil at the ocean floor following Deepwater Horizon. Proc Natl Acad Sci U S A, 114, E9-E18. https://doi.org/10.1073/ pnas. 1610110114

Bennett, B., \& Larter, S. R. (2000). Quantitative separation of aliphatic and aromatic hydrocarbons using silver ionsilica solid-phase extraction. Analytical Chemistry, 72, 1039-1044. https://doi.org/10.1021/ac9910482

Beyer, J., Trannum, H. C., Bakke, T., Hodson, P. V., \& Collier, T. K. (2016). Environmental effects of the Deepwater Horizon oil spill: A review. Marine Pollution Bulletin, 110, 28-51. https://doi.org/10.1016/j.marpolbul.2016.06. 027

Bochdansky, A. B., van Aken, H. M., \& Herndl, G. J. (2010). Role of macroscopic particles in deep-sea oxygen consumption. Proceedings of the National Academy of Sciences, 107, 8287-8291. https://doi.org/10.1073/pnas. 0913744107

BP Gulf Science Data (2017). Chemical analysis and physical properties of weathered, unweathered, and surrogate crude oils from the Deepwater Horizon accident in the Gulf of Mexico, July 2010 to January 2011. Distributed by: Gulf of Mexico Research Initiative Information and Data Cooperative (GRIIDC), Harte Research Institute, Texas A\&M University-Corpus Christi. http://data.gulfr esearchinitiative.org/data/BP.x750.000:0003.

Brooks, G. R., Larson, R. A., Schwing, P. T., Romero, I., Moore, C., Reichart, G.-J., Jilbert, T., Chanton, J. P., Hastings, D. W., Overholt, W. A., Marks, K. P., Kostka, J. E., Holmes, C. W., \& Hollander, D. (2015). Sedimentation pulse in the NE Gulf of Mexico following the $2010 \mathrm{DWH}$ blowout. PLoS ONE, 10, e0132341. https://doi.org/10. 1371/journal.pone. 0132341

Camilli, R., Reddy, C. M., Yoerger, D. R., Van Mooy, B. A. S., Jakuba, M. V., Kinsey, J. C., McIntyre, C. P., Sylva, S. P., \& Maloney, J. V. (2010). Tracking hydrocarbon plume transport and biodegradation at Deepwater Horizon. Science, 330, 201-204. https://doi.org/10.1126/science. 1195223

Campbell, L. G., Thrash, J. C., Rabalais, N. N., \& Mason, O. U. (2019). Extent of the annual Gulf of Mexico hypoxic zone influences microbial community structure. PLoS ONE, 14, e0209055-e0209055. https://doi.org/10.1371/ journal.pone.0209055

Chanton, J., Zhao, T., Rosenheim, B. E., Joye, S., Bosman, S., Brunner, C., Yeager, K. M., Diercks, A. R., \& Hollander, D. (2015). Using natural abundance radiocarbon to trace the flux of petrocarbon to the seafloor following the Deepwater Horizon oil spill. Environmental Science and Technology, 49, 847-854. https://doi.org/10.1021/es5046524

Chikere, C.B., Okpokwasili, G.C. \& Chikere, B.O. (2011). Monitoring of microbial hydrocarbon remediation in the soil. 3 Biotech, 1, 117-138. https://doi.org/10.1007/ s13205-011-0014-8.

Daly, K. L., Passow, U., Chanton, J., \& Hollander, D. (2016). Assessing the impacts of oil-associated marine snow formation and sedimentation during and after the Deepwater
Horizon oil spill. Anthropocene, 13, 18-33. https://doi. org/10.1016/j.ancene.2016.01.006

Dissanayake, A. L., Burd, A. B., Daly, K. L., Francis, S., \& Passow, U. (2018). Numerical modeling of the interactions of oil, marine snow, and riverine sediments in the ocean. Journal of Geophysical Research: Oceans, 123, 5388-5405. https://doi.org/10.1029/2018JC013790

Doyle, S. M., Whitaker, E. A., De Pascuale, V., Wade, T. L., Knap, A. H., Santschi, P. H., Quigg, A., \& Sylvan, J. B. (2018). Rapid formation of microbe-oil aggregates and changes in community composition in coastal surface water following exposure to oil and the dispersant corexit. Frontiers in Microbiology, 9, 689-689. https://doi.org/10. 3389/fmicb.2018.00689

Foekema, E.M., van Eenennaam, J.S., Hollander, D.J., Langenhoff, A.M., Oldenburg, T.B.P., Radović, J.R., Rohal, M., Romero, I.C., Schwing, P.T. \& Murk, A.J. 2020, Testing the effect of MOSSFA (marine oil snow sedimentation and flocculent accumulation) events in benthic microcosms, in S.A. Murawski, C.H. Ainsworth, S. Gilbert, D.J. Hollander, C.B. Paris, M. Schlüter and D.L. Wetzel (eds.), Scenarios and Responses to Future Deep Oil Spills: Fighting the Next War, Springer International Publishing, Cham, pp. 288-299. https://doi.org/ 10.1007/978-3-030-12963-7_17.

Gelpi, E., Schneider, H., Mann, J., \& Oró, J. (1970). Hydrocarbons of geochemical significance in microscopic algae. Phytochemistry, 9, 603-612. https://doi.org/10. 1016/S0031-9422(00)85700-3

Gregson, B.H., McKew, B.A., Holland, R.D., Nedwed, T.J., Prince, R.C. \& McGenity, T.J. (2021). Marine oil snow, a microbial perspective. Frontiers in Marine Science, 8. https://doi.org/10.3389/fmars.2021.619484.

Gutierrez, T., Morris, G., Ellis, D., Bowler, B., Jones, M., Salek, K., Mulloy, B., \& Teske, A. (2018). Hydrocarbon-degradation and MOS-formation capabilities of the dominant bacteria enriched in sea surface oil slicks during the Deepwater Horizon oil spill. Marine Pollution Bulletin, 135, 205-215. https://doi.org/10.1016/j.marpo lbul.2018.07.027

Hastings, D. W., Schwing, P. T., Brooks, G. R., Larson, R. A., Morford, J. L., Roeder, T., Quinn, K. A., Bartlett, T., Romero, I. C., \& Hollander, D. J. (2016). Changes in sediment redox conditions following the BP DWH blowout event. Deep Sea Research Part II: Topical Studies in Oceanography, 129, 167-178. https://doi.org/10.1016/j. dsr2.2014.12.009

Kleindienst, S., Paul, J. H., \& Joye, S. B. (2015). Using dispersants after oil spills: Impacts on the composition and activity of microbial communities. Nature Reviews Microbiology, 13, 388-396. https://doi.org/10.1038/ nrmicro3452

Kujawinski, E. B., Kido Soule, M. C., Valentine, D. L., Boysen, A. K., Longnecker, K., \& Redmond, M. C. (2011). Fate of dispersants associated with the Deepwater Horizon oil spill. Environmental Science \& Technology, 45, 1298-1306. https://doi.org/10.1021/es103838p

Larter, S., Silva, R. C., Marcano, N., Snowdon, L. R., Villarreal-Barajas, J. E., Sonei, R., Gutiérrez, L. C. P., Huang, H., Stopford, A., Oldenburg, T. B., \& Zhao, J. (2019). The dating of petroleum fluid residence time in 
subsurface reservoirs. Part 1: A radiolysis-based geochemical toolbox. Geochimica Et Cosmochimica Acta, 261, 305-326.

Lee, D.-H., Cody, R. D., Kim, D.-J., \& Choi, S. (2002). Effect of soil texture on surfactant-based remediation of hydrophobic organic-contaminated soil. Environment International, 27, 681-688. https://doi.org/10.1016/S01604120(01)00130-1

Li, Y., Yang, S., Wang, X., Hu, J., Cui, L., Huang, X., \& Jiang, W. (2016). Leaf wax n-alkane distributions in Chinese loess since the Last Glacial Maximum and implications for paleoclimate. Quaternary International, 399, 190197. https://doi.org/10.1016/j.quaint.2015.04.029

Lincoln, S.A., Radović, J.R., Gracia, A., Jaggi, A., Oldenburg, T.B.P., Larter, S.R. \& Freeman, K.H. 2020, Molecular legacy of the 1979 Ixtoc 1 oil spill in deep-sea sediments of the southern Gulf of Mexico, in S.A. Murawski, C.H. Ainsworth, S. Gilbert, D.J. Hollander, C.B. Paris, M. Schlüter and D.L. Wetzel (eds.), Deep Oil Spills: Facts, Fate, and Effects, Springer International Publishing, Cham, pp. 312-327. https://doi.org/10.1007/978-3-03011605-7_19.

MacDonald, I. R., Garcia-Pineda, O., Beet, A., Daneshgar Asl, S., Feng, L., Graettinger, G., French-McCay, D., Holmes, J., Hu, C., Huffer, F., Leifer, I., Muller-Karger, F., Solow, A., Silva, M., \& Swayze, G. (2015). Natural and unnatural oil slicks in the Gulf of Mexico. Journal of Geophysical Research: Oceans, 120, 8364-8380. https://doi.org/10. 1002/2015JC011062

Malone, K., Pesch, S., Schlüter, M., \& Krause, D. (2018). Oil droplet size distributions in deep-sea blowouts: Influence of pressure and dissolved gases. Environmental Science \& Technology, 52, 6326-6333. https://doi.org/10.1021/acs. est.8b00587

Mukherjee, A. K., Bhagowati, P., Biswa, B. B., Chanda, A., \& Kalita, B. (2017). A comparative intracellular proteomic profiling of Pseudomonas aeruginosa strain ASP-53 grown on pyrene or glucose as sole source of carbon and identification of some key enzymes of pyrene biodegradation pathway. Journal of Proteomics, 167, 25-35. https:// doi.org/10.1016/j.jprot.2017.07.020

Nzila, A. (2018). Current status of the degradation of aliphatic and aromatic petroleum hydrocarbons by thermophilic microbes and future perspectives. International Journal of Environmental Research and Public Health, 15, 2782. https://doi.org/10.3390/ijerph15122782

Passow, U., Ziervogel, K., Asper, V., \& Diercks, A. (2012). Marine snow formation in the aftermath of the Deepwater Horizon oil spill in the Gulf of Mexico. Environmental Research Letters, 7, 035301. https://doi.org/10.1088/ 1748-9326/7/3/035301

Pelegrí, S. P., \& Blackburn, T. H. (1994). Bioturbation effects of the amphipod Corophium volutator on microbial nitrogen transformations in marine sediments. Marine Biology, 121, 253-258. https://doi.org/10.1007/BF00346733

Peterson, C. H., Anderson, S. S., Cherr, G. N., Ambrose, R. F., Anghera, S., Bay, S., Blum, M., Condon, R., Dean, T. A., Graham, M., Guzy, M., Hampton, S., Joye, S., Lambrinos, J., Mate, B., Meffert, D., Powers, S. P., Somasundaran, P., Spies, R. B., ... Adams, E. E. (2012). A tale of two spills: Novel science and policy implications of an emerging new oil spill model. BioScience, 62, 461-469. https://doi.org/ 10.1525/bio.2012.62.5.7

Prince, R. C., Butler, J. D., \& Redman, A. D. (2017). The rate of crude oil biodegradation in the sea. Environmental Science \& Technology, 51, 1278-1284. https://doi.org/10. 1021/acs.est.6b03207

Quigg, A., Passow, U., Daly, K.L., Burd, A., Hollander, D.J., Schwing, P.T. \& Lee, K. 2020, Marine oil snow sedimentation and flocculent accumulation (MOSSFA) events: Learning from the past to predict the future, in S.A. Murawski, C.H. Ainsworth, S. Gilbert, D.J. Hollander, C.B. Paris, M. Schlüter and D.L. Wetzel (eds.), Deep oil spills: Facts, fate, and effects, Springer International Publishing, Cham, pp. 196-220. https://doi.org/10.1007/9783-030-11605-7_12.

Radović, J. R., Aeppli, C., Nelson, R. K., Jimenez, N., Reddy, C. M., Bayona, J. M., \& Albaigés, J. (2014). Assessment of photochemical processes in marine oil spill fingerprinting. Marine Pollution Bulletin, 79, 268-277. https://doi. org/10.1016/j.marpolbul.2013.11.029

Rahsepar, S., Langenhoff, A. A. M., Smit, M. P. J., van Eenennaam, J. S., Murk, A. J., \& Rijnaarts, H. H. M. (2017). Oil biodegradation: Interactions of artificial marine snow, clay particles, oil and Corexit. Marine Pollution Bulletin, 125, 186-191. https://doi.org/10. 1016/j.marpolbul.2017.08.021

Rahsepar, S., Smit, M. P. J., Murk, A. J., Rijnaarts, H. H. M., \& Langenhoff, A. A. M. (2016). Chemical dispersants: Oil biodegradation friend or foe? Marine Pollution Bulletin, 108, 113-119. https://doi.org/10.1016/j.marpolbul.2016. 04.044

Reddy, C. M., Arey, J. S., Seewald, J. S., Sylva, S. P., Lemkau, K. L., Nelson, R. K., Carmichael, C. A., McIntyre, C. P., Fenwick, J., Ventura, G. T., Van Mooy, B. A. S., \& Camilli, R. (2012). Composition and fate of gas and oil released to the water column during the Deepwater Horizon oil spill. Proceedings of the National Academy of Sciences, 109, 20229-20234. https://doi.org/10.1073/pnas. 1101242108

Romero, I. C., Schwing, P. T., Brooks, G. R., Larson, R. A., Hastings, D. W., Ellis, G., Goddard, E. A., \& Hollander, D. J. (2015). Hydrocarbons in deep-sea sediments following the 2010 Deepwater Horizon blowout in the Northeast Gulf of Mexico. PLoS ONE, 10, e0128371. https://doi. org/10.1371/journal.pone.0128371

Romero, I. C., Toro-Farmer, G., Diercks, A.-R., Schwing, P., Muller-Karger, F., Murawski, S., \& Hollander, D. J. (2017). Large-scale deposition of weathered oil in the Gulf of Mexico following a deep-water oil spill. Environmental Pollution, 228, 179-189. https://doi.org/10.1016/j. envpol.2017.05.019

Schedler, M., Hiessl, R., Valladares Juárez, A. G., Gust, G., \& Müller, R. (2014). Effect of high pressure on hydrocarbon-degrading bacteria. AMB Express, 4, 77. https://doi. org/10.1186/s13568-014-0077-0

Schwing, P.T., Hollander, D.J., Brooks, G.R., Larson, R.A., Hastings, D.W., Chanton, J.P., Lincoln, S.A., Radović, J.R. \& Langenhoff, A. 2020, The sedimentary record of MOSSFA events in the Gulf of Mexico: A comparison of the Deepwater Horizon (2010) and Ixtoc 1 (1979) oil spills, in S.A. Murawski, C.H. Ainsworth, S. Gilbert, D.J. 
Hollander, C.B. Paris, M. Schlüter and D.L. Wetzel (eds.), Deep oil spills: Facts, fate, and effects, Springer International Publishing, Cham, pp. 221-234. https://doi.org/10. 1007/978-3-030-11605-7_13.

Schwing, P. T., O’Malley, B. J., \& Hollander, D. J. (2018). Resilience of benthic foraminifera in the Northern Gulf of Mexico following the Deepwater Horizon event (20112015). Ecological Indicators, 84, 753-764. https://doi.org/ 10.1016/j.ecolind.2017.09.044

Shanks, A. L., \& Trent, J. D. (1980). Marine snow: Sinking rates and potential role in vertical flux. Deep Sea Research Part A Oceanographic Research Papers, 27, 137-143. https://doi.org/10.1016/0198-0149(80)90092-8

Shrivastava, R. \& Phale, P.S. 2012, Biodegradation of monoaromatic compounds by bacteria, in T. Satyanarayana and B.N. Johri (eds.), Microorganisms in Environmental Management: Microbes and Environment, Springer Netherlands, Dordrecht, pp. 451-476. https://doi.org/10.1007/ 978-94-007-2229-3_21.

Sohm, J. A., Edwards, B. R., Wilson, B. G., \& Webb, E. A. (2011). Constitutive Extracellular Polysaccharide (EPS) production by specific isolates of Crocosphaera watsonii. Frontiers in Microbiology, 2, 229. https://doi.org/10.3389/ fmicb.2011.00229

Soloviev, A. V., Haus, B. K., McGauley, M. G., Dean, C. W., Ortiz-Suslow, D. G., Laxague, N. J. M., \& Özgökmen, T. M. (2016). Surface dynamics of crude and weathered oil in the presence of dispersants: Laboratory experiment and numerical simulation. Journal of Geophysical Research: Oceans, 121, 3502-3516. https://doi.org/10.1002/2015J C011533

Stout, S. A., Payne, J. R., Ricker, R. W., Baker, G., \& Lewis, C. (2016). Macondo oil in deep-sea sediments: Part 2 - Distribution and distinction from background and natural oil seeps. Marine Pollution Bulletin, 111, 381-401. https:// doi.org/10.1016/j.marpolbul.2016.07.041

Stout, S. A., Rouhani, S., Liu, B., Oehrig, J., Ricker, R. W., Baker, G., \& Lewis, C. (2017). Assessing the footprint and volume of oil deposited in deep-sea sediments following the Deepwater Horizon oil spill. Marine Pollution Bulletin, 114, 327-342. https://doi.org/10.1016/j.marpo lbul.2016.09.046

Thornton, D. C. O. (2002). Diatom aggregation in the sea: Mechanisms and ecological implications. European Journal of Phycology, 37, 149-161. https://doi.org/10.1017/ S0967026202003657

van Eenennaam, J. S., Rahsepar, S., Radović, J. R., Oldenburg, T. B. P., Wonink, J., Langenhoff, A. A. M., Murk, A. J., \& Foekema, E. M. (2018). Marine snow increases the adverse effects of oil on benthic invertebrates. Marine Pollution Bulletin, 126, 339-348. https://doi.org/10. 1016/j.marpolbul.2017.11.028

van Eenennaam, J. S., Rohal, M., Montagna, P. A., Radović, J. R., Oldenburg, T. B. P., Romero, I. C., Murk, A. J., \&
Foekema, E. M. (2019). Ecotoxicological benthic impacts of experimental oil-contaminated marine snow deposition. Marine Pollution Bulletin, 141, 164-175. https://doi.org/ 10.1016/j.marpolbul.2019.02.025

van Eenennaam, J. S., Wei, Y., Grolle, K. C. F., Foekema, E. M., \& Murk, A. J. (2016). Oil spill dispersants induce formation of marine snow by phytoplankton-associated bacteria. Marine Pollution Bulletin, 104, 294-302. https://doi. org/10.1016/j.marpolbul.2016.01.005

Vonk, S. M., Hollander, D. J., \& Murk, A. J. (2015). Was the extreme and wide-spread marine oil-snow sedimentation and flocculent accumulation (MOSSFA) event during the Deepwater Horizon blow-out unique? Marine Pollution Bulletin, 100, 5-12. https://doi.org/10.1016/j.marpolbul. 2015.08.023

Wimpenny, J. \& Poole, R.K. 2009, Microbial metropolis, Advances in Microbial Physiology, Academic Press, pp. 29-84. https://doi.org/10.1016/S0065-2911(09)05602-1.

Wotton, R. 2004, The essential role of exopolymers (Eps) in aquatic systems, Oceanography and Marine Biology, CRC Press, pp. 57-94. https://doi.org/10.1201/97802 03507810.ch3.

Xu, X., Liu, W., Tian, S., Wang, W., Qi, Q., Jiang, P., Gao, X., Li, F., Li, H. \& Yu, H. (2018). Petroleum hydrocarbondegrading bacteria for the remediation of oil pollution under aerobic conditions: A perspective analysis. Frontiers in Microbiology, 9. https://doi.org/10.3389/fmicb. 2018.02885.

Yan, B., Passow, U., Chanton, J. P., Nöthig, E.-M., Asper, V., Sweet, J., Pitiranggon, M., Diercks, A., \& Pak, D. (2016). Sustained deposition of contaminants from the Deepwater Horizon spill. Proceedings of the National Academy of Sciences, 113, E3332. https://doi.org/10.1073/pnas.15131 56113

Zeinstra-Helfrich, M., Koops, W., Dijkstra, K., \& Murk, A. J. (2015). Quantification of the effect of oil layer thickness on entrainment of surface oil. Marine Pollution Bulletin, 96, 401-409. https://doi.org/10.1016/j.marpolbul.2015.04. 015

Zuijdgeest, A., \& Huettel, M. (2012). Dispersants as used in response to the MC252-spill lead to higher mobility of polycyclic aromatic hydrocarbons in oil-contaminated Gulf of Mexico sand. PLOS ONE, 7, e50549. https://doi. org/10.1371/journal.pone.0050549

Publisher's Note Springer Nature remains neutral with regard to jurisdictional claims in published maps and institutional affiliations. 